\title{
The spectre-image: A hauntology of Skoonheid and Kanarie
}

$>\quad$ Chantelle Gray

North-West University, Potchefstroom, South Africa.

gray.chantelle@gmail.com (ORCID: https://orcid.org/0000-0003-1061-4463)

\section{ABSTRACT}

The aim of this paper is to interrogate and trace the ghosts of heteronormative whiteness - and thus the spectres of queerness and blackness, specifically racial erasure through gendered foregrounding - in two recent motion pictures dealing with white, Afrikaner homosexuality, namely the 2011 film, Skoonheid (Beauty) and the 2018 film Kanarie (Canary). My aim is to look beyond the ostensible strengths of these films in terms of their representations of Afrikaner homosexual masculinities, both during and since the disbandment of apartheid, in order to see whether these films are indeed as politically progressive as they seem to be. Drawing on Gilles Deleuze's cinema books and Jacques Derrida's notion of hauntology - a wordplay on 'haunting' and 'ontology' - I investigate here the ways in which subjectivities and geographies (place/space) in Skoonheid and Kanarie produce and reproduce knowledges about race, gender and difference, and map some ways in which these are assimilated into socio-political, geographical and temporal configurations through what I call the spectre-image.

Keywords: Counter-enunciations, hauntology, racial erasure, spectre-image, structural absence.

Published by

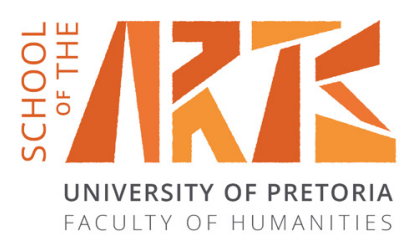




\section{Spectres of African cinema}

Although important segues towards the de-westernisation and decolonisation of film studies have been made, including critiques of so-called Global North 'ideologies, theoretical and historical frameworks, critical perspectives', and 'institutional and artistic practices' (Maty Bâ \& Higbee 2012:1), hegemonic traces nonetheless remain. As Trinh Minh-ha (1989:3) puts it,

[w]hat is at stake is not only the hegemony of Western cultures, but also their identities as unified cultures; in other words the realization that there is a Third World in every first and vice versa.

Of particular importance to this paper is precisely this interweaving between the "Global South" and "Global North", especially as pertains to race, gender and geography in film studies, as well as their attendant politics. On this point, Steve Neale (2014:10) argues that the 'inter-textual relay' between issues related to the publicity and marketing of the film industry as it weaves into and through institutional discourses via, for example the media and academia, and unofficial 'discourses of everyday life', play crucial roles. In terms of sexuality and gender, many of the early debates centred on 'the spectacle of a "sexually saturated" female body' (Williams 2014:44) and women as 'passive image' with man as 'the active bearer of the look' (Williams 2014:44; cf. Mulvey 1975). The grotesque, too, has a long history associated with women, both in literature and film. Seemingly contradictory, the grotesque signals the erotic. For example, in horror movies the typical portrayal of male dominance and power over the female "victim" is grotesque, ${ }^{1}$ such as in slasher movies, but also erotic in terms of the gaze. While this is the norm, many films have resisted such clichéd depictions in favour of more nuanced perspectives (see Clover 2014), though these kinds of overdeterminations, underrepresentations, passé representations, Freudian interpretations, reinforcements of the male gaze, and resistance to all of these demonstrate the complexity of these enduring practices and debates.

African films first began to appear during the late 1950s and early 1960s. 'Starting in the late 1960s, and especially in the 1970s, the rhetoric of struggle began to turn from anticolonialism to protest against African elites' (Harrow 1999:xiv; see also Modisane 2013). Perhaps one of the most crucial aspects in thinking about African cinema and de-Westernised theorisation is how to incorporate oral histories in film, as ontologies 'shaped by orality assume that the world consists of interacting forces of cosmological scale and significance rather than of discrete secularised concrete objects' (Tomaselli, Shepperson \& Eke 1999:45). This focus on orality, cosmology and community, argues Clyde Taylor (2000:143), forms the basis of some of the paradoxes of 'the greater impact of African films on the sensitive observer over their Western alternatives' as 
the connection to and 'intuition of communal relatedness' trouble western ontologies and individualism.

Correspondingly, the queer figure has, at least since the early 2000s, gained increasing prominence in the political and cultural arenas of Africa, as many debates and contestations have emerged regarding the "production and circulation of African queer representations' (Osinubi 2016:viii). Although queer representation in these contexts predate 'the recent wave of repressive legislation' which, importantly, does not extend evenly throughout the continent, the 'emergent representations have lately been framed as interventions in cultural politics or expressions of dissent due to the politicization of queer intimacies' (Osinubi 2016:viii). The queer figure, as such, pivots quite strongly on absent/present spectres, their presences visible, oblique, invisible and overvisibilised at different times. Despite this, Taiwo Adetunji Osinubi (2016:x) argues that even 'negative representations were largely unthinkable twenty years ago', which attests to the widespread transformation in the various African literary and film industries.

South Africa has often been hailed as pioneering in the recognition and protection of sexual minorities, at least in terms of constitutional rights from the time when apartheid was disbanded, although the clash between customary and civil law remains frictive (see Hoad 2016). Without negating the constitutional precedents of South Africa and its contributions to queer African cinema, it is noteworthy that other African countries have also, and continue to, produce queer films that destabilise both gender and racial grids, often under the threat of criminalisation and punishment. In Senegal, for example, 'homosexuality is condemned by law' (Stobie 2016:87), yet the country produced the film Karmen Geï (2001), an adaptation of George Bizet's 1875 opera, Carmen, with queer inflections, notably around bisexuality. The film not only disrupts Bizet's heterosexual relations, but also encourages a queer bisexual analysis, where bisexuality is shown as to be a complex site that intersects race, gender and geography. Similarly, Socrate Safo's Women in Love (1996) also broaches homosexuality, following the Ghanaian tradition of video-films aimed at producing an 'aesthetics of outrage' (Green-Simms 2012:28), notwithstanding same-sex acts being criminalised in Ghana. Lindsey Green-Simms (2012:30) argues that West-African video-film emerged from 'within an increasingly religious and spiritual milieu' and thus demands that we pay attention to the in/visible revenants of "occult forces just as much as it requires a feminist framework to understand the way in which gender is constructed through the films'. There is thus a sense in which the supernatural insouciantly operates alongside ordinary experience. The occult - but also religion in general, as I show in Skoonheid and Kanarie - therefore refers to far more than the spiritual, as it gestures forbidden desire and the haunting of 'unrepresentable desires and fears' that 'are channelled through the supernatural and, more specifically, the diabolical' (Green- 
Simms 2012:28). Karl Schoonover and Rosaline Galt (2016:221) likewise argue that there exists a 'closeness of queer melodrama to political activism' in African films, as is evident, for example, from movements around the 2017 South African film, Inxeba (The Wound), and the 2018 Kenyan film, Rafiki (Friend). Both Skoonheid and Kanarie can be seen as informed by these contexts.

\section{Skoonheid and Kanarie: a hauntological outline}

A recurring theme in South African film is that of trauma. Considering the legacy of colonialism and apartheid, this comes as no surprise. In post-apartheid South Africa, 'audiences were exposed to certain marginalized communities' for the first time - at least as far as it was now lawfully sanctioned - ranging from the homeless and poor, to AIDS orphans and victims, to gays and lesbians. ${ }^{2}$ While differing in scope and narrative, many of these films chronicle the past and the future, as well as attempts to bridge these. This is no less true of the two films under discussion, namely Skoonheid and Kanarie.

The first film, Oliver Hermanus's Skoonheid - Beauty in English, although the Afrikaans word denotes both beauty and cleanliness - follows the life of Francois van Heerden (Deon Lotz), a typical Afrikaner patriarch within a characteristically Afrikaner milieu, namely the Free State, which was 'one of the firmest bastions of Afrikaner power under apartheid' (Verwey \& Quayle 2012:557). Francois, at first glance, is an ordinary husband with a loving wife, two daughters, and a well-established business. However, the viewer soon discovers that Francois is living a double life, expressing his 'homosexual desires within a secretive grouping of similar men, who meet at empty houses for group sex sessions that are awkwardly framed within a social discourse of heterosexual machismo' (Falkof 2016:9).

Unlike the sustained disquiet of Skoonheid, Kanarie, directed by Christiaan Olwagen, vacillates between relative gravity and gaiety following the style of a musical drama. Set in 1985, against the backdrop of the South African Border War, also known as the Namibian War of Independence, we follow the life of Johan Niemand (Schalk Bezuidenhout), introduced to the viewer as an effeminate admirer of Boy George. Early in the film, Johan is conscripted into the South African Defence Force (SADF) but, in order to avoid the battlefield, he auditions for the Kanaries (meaning "Canaries"), the Defence Force's church and concert choir. During the first year, Johan falls in love with a fellow Kanarie and begins to notice some of the subjugation and discrimination around him. 
These two films mark an important turn in mainstream Afrikaans cinema, as gay characters have characteristically been 'diminished to cliché-ridden background figures' (Eloff 2018). This underrepresentation of local queer lived realities can 'be seen as symptomatic of this repression within broader South African society' (Andrews 2018:32). As such, Skoonheid and Kanarie are significant not only for their contributions to African and queer cinema, but also for their engagement with the ethics of desire. The characters' grappling with the private/public identity crisis suffered by many white, gay men under the conservative laws of apartheid, 'informed by Christian Nationalist ideology' and bolstered 'by the Dutch Reformed Church, which placed great emphasis on morality, asceticism, industriousness and heteronormativity' (Sonnekus 2013:24), therefore potentially becomes the viewers' struggle too. Consequently, both Skoonheid and Kanarie hold the power to rupture reified paradigms - or what Deleuze might call 'dogmatic images of thought'3 - about masculine subjecthood through real sociopolitical as well as personal and affective dimensions.

Within the films we find lines of identity intersecting with race, gender and geography; that is, structural racism and structural patriarchy which function to uphold white supremacy ${ }^{4}$ and compulsory heterosexuality, as well as 'their attendant geographies', themselves imbricated in 'material and metaphorical space' (McKittrick 2006:xiii) - in this instance, the Free State (Skoonheid) and the military (Kanarie). However, while the two films subvert compulsory heteronormativity, I argue that they contribute - at least to some degree - to the 'process of social concealment and dehumanization' of 'black subjectivity' (McKittrick 2006:xiii, emphasis in original), therefore continuing to collaborate in the apparatuses of what Robin DiAngelo (2018) calls 'white fragility' - white people's conscious and unconscious investments in upholding white institutional power. ${ }^{5}$ These recurring dis/positionalities provide viable sites for a hauntological reading because the humanising of white, gay male figures under apartheid potentially elides the complicity of all whites in white supremacy - if not through ideological interpellation, then through structural stratification (white privilege). Moreover, these gender and race stratifications have direct bearing on the socio-spatio-politicaltemporal configurations of bodies and the ways in which the material and 'imaginative body-self necessarily interprets space and place - in its limitations and its possibilities' (McKittrick 2006:2).

Drawing on Gilles Deleuze's cinema books and Jacques Derrida's notion of hauntology, I argue here that the spectre-image offers a new kind of mapping - a hauntology or spectrography. Moreover, hauntology is rooted in the uncanny, which asks of us 'that we become more comfortable with discomfort, with uncomfortable affective relations, haecceities and spectral entanglements' (Carstens 2018:352). The spectre-image, then, resides in a place of limbo: neither here, nor there; neither dead, nor alive; neither 
an image that is fully extensive, nor an image that is fully Ideal; simply a haunting in the ruins of images which, 'in the tradition of the symbolism of horror', points always 'to the scene of ghost-producing violence' (Tuck \& Ree 2013:653). Thus, I invite the ghosts of the past into a hauntological engagement with memory in order to produce counter-enunciations, counter-temporalities and counter-genealogies in the philosophy of cinema through what I word the "spectre-image". 6

\section{A crisis of perception: from the movement-image to the time-image}

Towards the end of Cinema 1, Deleuze (1986) argues that post-World War II brought about a crisis in perception so that a new type of consciousness was developing. Instead of the movement-images of early cinema, which followed motor-sensory action in relatively linear ways, a new kind of image emerged, namely time-images. Quite unlike the movement-image, the relations between time-images are no longer ordered by the sensorimotor schema and contain affective forces with the potential to create topological 'openings' where crystalline images allow us to perceive time directly. Thus, time, in the time-image, is no longer subordinate to movement. Rather, movement is subordinate to time so that the movement-image becomes a dimension of the timeimage. Instead of sensorimotor experience directing the perception of time on the screen and in brain-screens, politics takes centre stage which, according to Deleuze, means that the temporal structure of the time-image is no longer primarily concerned with movement and space, but with temporality and topology; that is, with the creation or genesis of conceptual fields.

Thus, cinema, like cognition or perception, consists of a set of concepts or images of thought that are multi-scalar, multi-temporal, and contextual. However, whereas the movement-image signals the material aspects of screen-subjectivity, the timeimage signals the relations between materiality and the immaterial. It therefore has political implications, including the 'production of racialized and gendered' spaces (McKittrick 2006:19). The implications are that the cinematographic consciousness becomes a political consciousness - a 'politics of the image' where the private is 'immediately political' (Deleuze 1989:193, 218). Moreover, Deleuze (1989) argues that temporality and subjectivity should be viewed in terms of an orientation towards the future. He writes,

[w] hat constitutes the crystal-image is the most fundamental operation of time: since the past is constituted not after the present that it was but at the same time, time has to split itself in two at each moment as present and past, which differ from each other in nature, or, what amounts to the same thing, it has to split the present in two heterogeneous directions, one of which is launched towards the future while the other falls into the past (Deleuze 1989:81). 
To put it simply, crystal-images make possible a non-representational semiotics of movement in matter as they rupture representation and the imposed linearity of time on narratives. Because time is apprehended directly here, the actual and virtual are no longer distinct. ${ }^{7}$ As such, the time-image creates a break in the sensory-motor schema of memory and narration, subverting the linear continuity and consistency of time. This, for Deleuze (1989:217), allows cinema to become political - to invent a missing people 'in new conditions of struggle to which a necessarily political art must contribute'. The time-image is thus also creative: genetic and generative in that it makes perceptible 'relationships of time which cannot be seen in the represented object and do not allow themselves to be reduced to the present' (Deleuze 1989:xii, emphasis added).

\section{The spectre-image: Deleuze with Derrida}

Spectrality and temporality are deeply entwined but, as Derrida argues, 'haunting is historical, to be sure, but it is not dated, it is never docilely given a date in the chain of presents' (1994:4, emphasis in original). Because the temporality of ghosts is not dated but historical, it necessarily relates to configurations of both subjecthood and place, though it is not reducible to these. Bound to histories of geography, the perception of space 'entails a gathering of stories around a location; the producer of a spectrography is therefore responsible for the creation' of a necessarily partial ethics, one which never claims 'to tell in full' (Pilar Blanco \& Peeren 2013b:483). In cinema, this spectrography is created though its 'phantomenological apparatus' so that 'one cannot untangle the past, present or future; it takes the outside in, processes it, and then projects the inside out in a way that undoes those divisions' (Hochhar-Lindgren 2011:131). This collapse of temporal divisions allows the screen-image and brainscreens to meet affectively and this, precisely, is the moment when viewers can apprehend the figure of the spectre directly. Here, then, lies the potential for an ethical encounter 'that eschews burial (associated with melancholia) or mastery (colonization) of the past in favor of the permission to mourn (to be revisited by a demand)' (Pilar Blanco \& Peeren 2013a:311) - to sit with ghosts in the untimely quieting, even disquieting, unknowing. Thus, the ghosts of the spectre-image 'permit us to mourn; they are, indeed, a sign of trauma and its mourning' and mourning, in turn, 'is, in an important way, the work of history' (Freccero 2013:338), the work of the present and the work of the future, the yet-to-come. Furthermore, hauntology upsets the histories and presents of "truths" and "facts" so that mourning, especially in the form of white guilt, does not remain trapped in the past, but 'takes charge of the future and freedom, provided that it leaves the crystal. Then the real will be created; at the same time as it escapes the eternal referral back of the actual and the virtual, the present and the past' (Deleuze 1989:88). 
In investigating the spectre-image as a new cinematographic conception, a philosophical exploration and a pervasive - though not all-encompassing - social consciousness, I concentrate on two aspects in particular, namely structural absence as related to subjectivity, and occult landscapes as related to geographies (place/space) and show how these function through analyses of the films Skoonheid and Kanarie. What I aim to show is that the politics of contemporary cinema almost always inhabit spaces that are connected to the expressions, materiality, immateriality, reality and indeed spectres of white supremacy. However, alongside the language and physicality of white geographies and spaces we also find 'a kind of geographic genealogy' that 'couples black geographies with black knowledges' and which expose white practices of ghettoization (McKittrick 2006:22).

\section{Structural absence}

The historic dominance of whiteness - or what Rey Chow (2002:3) calls 'the ascendency of whiteness', and what we can also refer to as structural racism or white supremacy - has long figured as a normative apparatus and biopolitical control measure. Expressed, manifested and developed in numerous ways and over many years, for example through histories of slavery, colonialism, institutionalised apartheid in South Africa, immigration laws, hetero- and homonormativity, and other despotic stratifications, we notice 'a conceptual order of things, an animate hierarchy of possible acts', taking shape (Chen 2012:3). Within these animate hierarchies, "built on the recognition that abstract concepts, inanimate objects, and things in between can be queered and racialized without human bodies present, quite beyond questions of personification' (Chen 2012:265), we can identify at least three important aspects related to whiteness.

The first is that structural whiteness, as seen through a biopolitical lens, is at once a problem of the individual and the social, including forms of social production with its associated systemic apparatuses, capitalist and neoliberal agendas, normative processes and de/securitisation practices. Second, we find interior to the individuating and socialising functions of structural whiteness an epistemic stratification reliant on a present/absent dualism that I call "structural absence". What structural absence effectuates in terms of race is that whiteness functions as 'a universal category that hides its specific values' and epistemologies so that its omnipresence renders it invisible, an 'unacknowledged racial category' that acquires and fortifies its power by negating its identity (Keating 1995:904, 905). By 'thus erasing its presence, "whiteness" operates as the unacknowledged standard or norm against which all so-called "minorities" are measured' (Keating 1995:905). This is what Deleuze and Guattari (1987:167) refer to as the two main functions of faciality, namely signifying 
biunivocalisation and subjective binarisation - the divisive and hierarchising functions of race. Accordingly, structural whiteness relies on individuating and socialising functions, which themselves rely on structural absence that distils essentialist yet invisible traits into biopolitical control applications. As Deleuze and Guattari (1987:177) put it, '[y]ou don't so much have a face as slide into one'; that is, being white does not so much sanction 'preferred racial attributes' as it does 'a raceless subjectivity' (McLaren 1991:244) so that the hegemonic invisibility of whiteness structures all other racial categories as ontologically absent from humanity, positing (falsely) that only whiteness is knowable and measurable. This is made possible, at least in part, by structural absence that sets white subjecthood in opposition to Black objecthood.

In this schema, Blackness is ontologically negated by humanism and epistemologically absented by whiteness so that Black flesh becomes objectifiable and, under the space-time axioms of capitalism, artificially scalable as is evident from histories of slavery. However, while the space-time of capital is abstract, it still locates itself in and through bodies - some more than others - as well as spaces and places, allowing some 'subjects to literally extend themselves into space, while others are rendered both absent and excessively present' (Taylor 2016:107), particularly in terms of race and gender. Moreover, stereotypical and essentialised depictions of race and gender have once again proliferated with the rise of the right-wing. These are the spectres of reality, the contours marking the border between what is perceived as "real" and "unreal”. Yet this 'being-with spectres', argues Derrida (1994:xix), is also 'a politics of memory, of inheritance, and of generations'. What is central to the 'figure of the spectre, then, is that it cannot be fully present: it has no being in itself but marks a relation to what is no longer or not yet' (Hagglund 2008:82).

Spectrality can therefore be said to have a double function - a double of experience - in that it functions as vectors of exposure and concealment. Hence, a 'study of hauntology' is a 'study of the spectre of race itself' - an account of the territorialising functions of trauma, but also of 'the possibilities of rebellion and escape' (Fisher 2012:24). The spectrality of being, which is not equivalent to presence, as Derrida ${ }^{8}$ argues, is therefore the hauntology that confronts whiteness 'with the kind of temporal disjunction that has been constitutive of the Afrodiasporic experience since Africans were first abducted by slavers and projected from their own lifeworld into the abstract space-time of Capital' (Fisher 2013:46). Moreover, it is 'proper to the time of "technotele-discursivity", "techno-tele-iconicity", "simulacra" and "synthetic images"' (Fisher 2012:19), rendering the hauntology of structural absence immanent to social consciousness and cinema through what I call the spectre-image. Importantly, the spectre-image does not only gesture abstemious subjectivity, but the carrying of a wound - tender in its gravity, but also wounding in its invention, and it is this wounding, this violent affect, I argue, that may allow for creative lines of flight. 
As seen in Kanarie, the systemic biases of apartheid relied on strict censorship laws that functioned to keep South Africa politically and socially conservative and isolated, thus limiting reality testing according to segregative aims, reinforced in insulated echo chambers. Moreover, Afrikaans was enforced as the official language and this linguistic contrivance perversely aided the national homophilia, resonated in and through religion, education and other familial and social systems so that the structural absence of people of colour was, largely, invisible and presumed. With little to no chance of encountering opposition, normative racialised and gendered ideas and practices flourished.

The first musical scene in Kanarie, a medium dolly shot, reveals a typical Afrikaner town, devoid of any people of colour on the street. The spectre-image here is that of the second synthesis - of memory - which gestures the past as it was as well as a hankering for it, a trait present in many, especially older, South Africans. Implementing both biunivocalisation and binarisation, the black/white absence/presence spectres apparate throughout the film. The same facialisation functions highlight the gender binaries. In this scene, all the young boys and girls are dressed to conform to normative ideas of the girl/boy binary, except for Johan, who is cross-dressed as Boy George in a wedding outfit. The overwhelmingly heteronormative, white setting is not lost on the viewer.

After drafting, the Kanaries are given a weekend pass and Johan and a few of his fellow Kanaries decide to go to a club in Lynwood (Pretoria). While there - a clearly white delineated space - the group starts singing to a song. At first shy, Johan joins in reluctantly but soon relinquishes control. In a jump-cut, we see Johan transform into Boy George, followed by the camera tracking a number of singer-dancers who transgress both the heterosexual and racial laws of the time. While this could be read as highly subversive, a ghostly tension remains here because the rebellion takes place only in Johan's imagination. Additionally, the singer-dancers represent pop stars from the 1980s. Thus, the fact that the Michael Jackson and Prince characters, for example, are people of colour, is not so much a revolt as an accurate image of thought. The spectre-image here transitions between the first and second syntheses of time, caught in representations that follow the individuating and socialising functions of structural whiteness. A raceless subjectivity is thus performed in that the scene is "colour blind" in a sense, its attempt at disruption devoid of real commentary on the racial divisions and subjugations in the country. The wounds of the spectre-images are revealed without allowing the spectre-image to wound in its invention. An important question lingers, '[w]hat is being screened, and what, thereby, is being kept from view?' (Hochhlar-Lindgren 2011:7). 
Ultimately, while some context is sketched in terms of historicity, no resistance to representational meaning escapes the digitised scene. The ephemeral eludes transference from screen to spectator so that the affective dimension of the sequence shot fails to transfigure into a disrupting montage sequence, remaining at the level of sensory-motor actualisations. The viewer encounters "cognition outside "the always non-arbitrary pre-prescribed", which underscores the ways in which subaltern lives are not marginal/other to regulatory classificatory systems, but instead integral to them' (McKittrick 2006:xxv, emphasis in original). Hence, black bodies effectively disappear to take up their designated ontological absence from humanism and their epistemological nonappearance in whiteness, the faciality of the colonial-nationalist machinery firmly in place. Furthermore, the foregrounding of nostalgia and white homosexual suffering conspires to distort the contemporaneity of the film and the larger tropes it plays into so that the audience is preoccupied more by phantom aesthetics than the experience of a real hauntological encounter that passages mourning into the crystals of time. Post-apartheid films, such as this one, de facto exclude the enduring conditions that racialised capitalism invisibilises through its post-truth machinery where 'the reality of black futures' is montaged counter to images of thought worthy of Black imaginations (Willoughby-Herard 2014:84), igniting colour-blind perceptions and discourses.

Notably, Afrikaans medium films are more often than not about and watched by white Afrikaners. This gives the impression that Afrikaans belongs to Afrikaners and Afrikanerdom (the culture of Afrikaners). The issue at stake here is how memory is positioned as it animates frames of denialism and deception which, in turn, feed into larger frames of social conformity and the confirmation biases of homogeneous groups. More importantly, the film relies on archival memory that presents time as nostalgia for the irretrievability of the past, even as it risks dis/positioning notions of Afrikaner masculinity. In short, Kanarie fails to invent a "missing people" as the colonised are depicted as little more than "cardboard people" and Johan's insights as nothing more than a paper revolt. The film thus remains at the level of representation instead of genesis or true creation.

\section{Occult landscapes}

In Demonic Grounds, Katherine McKittrick argues that subjectivities are imbricated in the 'language and the physicality of geography', imbued 'with sensations and distinct ways of knowing: rooms full of weeping, exhausted countries, a house that is only as safe as flesh' (2006:ix, xiii, emphasis in original). I have already referred to the role of Afrikaans, though it bears mentioning what Derrida (1992:80) has to say on the matter, '[l]anguage gives one to think but it also steals, spirits away from us, whispers to us 
[elle nous souffle], and withdraws the responsibility that it seems to inaugurate; it carries off the property of our own thoughts even before we have appropriated them'. To some extent, language thus determines social space and its possible worldings. Furthermore, distinctly racialised geographies were produced in apartheid South Africa through the Group Areas Act, which allocated racial groups to specific urbanand cityscapes. In this way, terrain became bound to racial identification so that the political enunciation of group identity came with 'assumptions about authenticity and encroachment' that continue to prevail (Taylor 2012:47).

Here we find an extension of facialisation onto the land - what Deleuze and Guattari call landscapification: the ghostly haunting of the face in a milieu. ${ }^{9}$ In brief, 'racialized processes are always and thoroughly spatialized ones' in that the territorial organisation of space is necessarily imbricated in the biopolitical control of subjects (Price 2010:147), the main aim being to uphold white supremacy. However, the 'pervasive nonpresence' of whiteness renders the analysis of whiteness as whiteness 'difficult - if not impossible' (Keating 1995:105). As a consequence, racialisation is as much a part of subjectivity as it 'is part of the normal, and normalized, landscape' (Kobayashi \& Peake 2000:392).

Skoonheid demonstrates the faciality-landscapification functions of whiteness very well. In the opening scene, 'a slow shot moves through a hall' where a wedding reception is taking place (Falkof 2016:19). The shot leads the viewer 'forward towards a good-looking young man', then cuts 'to a close-up of Francois' (Falkof 2016:19), the source of the camera's gaze. Similar close-up shots of Francois occur throughout the film so that his face frames the entire narrative, breaching the contours of his personal space to impinge on familial and social spaces, as well as geographic location. Closeup shots like these - and there are many throughout the film - demonstrate precisely the separation of the face from the body that is needed to allow faciality to take place. Thus, while the head is part of the body, coded by the body, the face is not and so ceases to be materially anchored and organised. Instead, the face becomes part of an abstracted, surface semiotic system that functions as a diagrammatic map of the field of subjective experience and possibility. In this way, the distilled Afrikaner face is made redundant because it is - and has been - repeated and spread through the entire social field.

'Ordinarily', writes Deleuze (1986:99), 'three roles of the face are recognisable'. Two of these were discussed earlier, namely the face's individuating and socialising roles. The third 'is relational or communicating (it ensures not only communication between two people, but also, in a single person, the internal agreement between his character and his role)' (Deleuze 1986:99). However, in close-up shots, the face loses these roles. Whereas the face usually functions to 'presuppose the reality of a state of things 
where people act and perceive', the close-up 'makes them dissolve, disappear' so that there is 'no close-up of the face'; rather, the 'close-up is the face, but the face precisely in so far as it has destroyed its triple function - a nudity of the face much greater than that of the body' (Deleuze 1986:99, emphasis in original).

The obsessive framing of Francois's face in the film invokes at least two spectreimages. The first relates to the present/absent epistemic stratification of structural whiteness that configures Francois in a raceless subjectivity. His face is the face of the normal that dis/positions both blackness and queerness as spectral; his overt heteronormativity propagates 'the propensity for gay and lesbian subjects to be culturally configured as ghosts' (Pilar Blanco \& Peeren 2013a:312). The second spectreimage sees Francois's face becoming the landscape. Hence, the ghosts of memory are invoked through the literary and visual archives of the plaasroman. Generally, in the pastoral novel, a 'landscape is humanised when inscribed by hand and plough' (Coetzee 1997:7) and so the 'farmer becomes husband to the land' (Wenzel 2000:94). The logic is typical of faciality and landscapification in that it signals a kind of familial and lineal cognisance 'where the farmer recognizes himself as a mediator between past and future generations, as a transitory steward of permanent family land' (Wenzel 2000:94). The plaasroman thus performs 'a curious ideological function' as it venerates 'a form of peasant agriculture and land ownership' that has been replaced in large by capitalist modes of being (Wenzel 2000:94). Concurrently, it also signals the postapartheid sentiment of Afrikaner dispossession and a longing for a return to die plaas (the farm).

The director cashes in on this when Francois drives to a pastoral home - set in a typical Afrikaner landscape - to meet with a group of men. The viewer follows Francois as he gets out of his bakkie (a pick-up truck, usually with an open back) and enters the house. Next, he walks through a dark corridor, then enters the kitchen. One of the men steps closer to greet him, while three other men stand at the opposite end of the room. The mood is edgy, although Francois nervously tries to ease the tension by drinking a beer and talking about the weather and braai-ing (barbequing). The rigidity eases when Francois is introduced to the other men in the room, only to be disturbed by the arrival of Gideon and his mixed-race "friend". Gideon tries to explain to the other men that his friend can be trusted and that he would never do anything to put their lives at risk, but the other men chase him out, stating clearly, '[n]o faggots, no coloureds. You know that'.

Having referenced the plaasroman, as well as archival memory of Afrikaner masculinity through both the visibility and invisibility of whiteness, the film deftly manages to mobilise faciality and landscapification hauntologically in such a way that the violent spectres of memory related to queerness and Blackness in both bodies and space/ 
place apparate to disturb the images on screen. What makes the scene remarkable is that the face-landscape complex leads the viewer ${ }^{10}$ to believe that the men are about to take part in something like a pro-apartheid meeting. This sense is reinforced when the kitchen scene jump-cuts to the farm image in a focused medium shot, only to jump-cut to a room where the spectator sees gay porn on a television screen, slowly becoming aware of men having sex with each other. The cognitive dissonance between this and the scene in the kitchen - particularly the 'no faggots, no coloureds' sentiment - emphasises the disappearance and disposability of queer and black bodies from space so that they become liminal presences, caught between the real and the unreal, even as the spectres of queerness and Blackness make visible the unequal distributions of power that whiteness enacted and continues to enact. As McKittrick (2006:xiv) argues, Blackness, and I want to add here queerness, 'is integral to the production of space' so that Black and queer subjects can be said to act as a ghostly un-mapping of the fabrication of space while being integral to its production for white heteronormative occupation.

The landscapification in Skoonheid ties into contemporary debates on fears around immigration, nationalism and belonging. These spectres of living and liveability are especially expressed through the 'Black-White binary that intersects with the Indigenous-Settler binary in ways that are mutually reinforcing' (Mahtani 2014:363), so that what we have here are the effects 'of an ontological treatment of the spectrality of the ghost' (Derrida 1994:91). Although these binaries have been powerful for the reshaping of social and cultural realities, laws and policies, and academic inquiry, they have also essentialised Black identities and underrepresented racial diversity. Consequently, the production of social space and geographical place is often presented as ahistorical so that Black lives can be reduced 'to essential measurable "facts" rather than presenting communities that have struggled, resisted and significantly contributed to the production of space' (McKittrick \& Woods 2007:6). In thinking about territory as 'social processes that make geography a racial-sexual terrain' (McKittrick 2006:xiv, emphasis in original), it is important to destabilise 'the stability of the binary opposition' (Price 2010:157) as this duality, along with the space/place/identity triad - a scalable temporality that projects regional and colonial nostalgia (anemoia) into/onto affective mappings of spaced selves. The spectres of the Free State, as a cultural ecology, relies on white/Black and heteronormative/ homosexual binaries as well as on the traces of dis/possession. 'It is significant', writes Theo Sonnekus (2013:31), 'that the white Afrikaans-speaking market is so dominant as well as being so frequently devoid of significant political themes'. In this sense, Skoonheid is effective in raising issues related to the apartheid landscape in terms of geography, race and gender, and destabilising the echo chambers of Afrikanerdom to a large degree. 
Kanarie, on the other hand, is less successful in this endeavour because even though militarism during apartheid is surfaced, the 'uneven spatial development of military spending and arms production' (Rogerson 1990:241) during this time is glossed over through the film's focus on white homosexual suffering and its glamourous film-making strategies. Elided are the ways in which the South African Border War destabilised neighbouring states - especially Angola - in an increasingly aggressive manner to bolster Afrikaner, and thus white supremacist, rule and legitimacy in an attempt to retain sovereignty over the then South West Africa region (now Namibia). Moreover, the Border War is construed as a reality that "just is". The savage colonisation of land is addressed only once in the film when a woman walks up to three of the Kanaries to thank them for their performance. Still in conversation, she asks them about their experience of the defence force. One of the young men answers, '[i]t's fun, ma'am. We meet lots of people'. She counters by asking them whether they have been to the townships (informal settlements where people of colour live). One of the young men says, '[o]f course not', and another adds, 'Ma'am we don't quite understand the question?'. A discussion ensues about the purpose of the war, the woman informing the Kanaries that the sole drive thereof is to 'keep whites in power'. One of the Kanaries retorts, '[n]o, we're fighting to keep things out of the country'. These "things" are objectified bodies rather than subjects - 'terrorists' and 'communists' in the young man's words.

What we see here in effect is how military frames, as memory devices, have a commemorative function that catalyse exceptionalism because it constructs a ruling elite 'selected by the reinforcement of systems of self-repression and by the promotion of segregatory models that result in a contempt for those' who fail to learn the game (Guattari 2016:78). Canons and histories are replete with such facialisation and landscapification functions, for example, the plantation in the US or townships in South Africa which, as enclosed spaces, provided a physical locality where racial division is normalised. Kanarie attempts to engage with these issues in the scene described, but the import thereof is drowned out by the spectacle of musical genre so that the spectres of the Border War and South Africa's role in the destabilisation of neighbouring countries to retain ownership of South West Africa/Namibia remains unchallenged. Thus, there is a denial of historical and contemporary complicity in the investment in white supremacy. This further dislocates the war from time and space, rendering it asynchronous, if not atemporal, and seemingly confined to a single border rather than a larger white nationalist territorial project. By thus centralising the place and role of the gendered body in the film, the importance of 'a black sense of place' is omitted (Mahtani 2014:361). 'An apt question is, then, under whose terms is geographic ignorance actually produced?' (McKittrick 2007:103). 


\section{Conclusion}

In this paper, I interrogated and traced the ghosts of heteronormative whiteness - and thus the spectres of queerness and blackness, specifically racial erasure through gendered foregrounding - in two recent motion pictures dealing with white Afrikaner homosexuality, namely the 2011 film, Skoonheid and the 2018 film, Kanarie. Looking beyond the ostensible strengths of these films in terms of their representations of Afrikaner homosexual masculinities, both during and since the disbandment of apartheid, I investigated whether these films are indeed as politically progressive as they seem to be. Drawing on Deleuze's cinema books and Derrida's notion of hauntology, I showed here the ways in which subjectivities and geographies (place/space) in Skoonheid and Kanarie produce and reproduce knowledges about race, gender and difference, and mapped some ways in which these are assimilated into socio-political, geographical and temporal configurations through what I call the spectre-image.

My contention is that the spectre-image reveals the oftentimes-overlooked relations between subjectivities and their attendant geographies. Accordingly, the spectreimage has two dimensions, namely structural absence and its epistemic stratifications reliant on facialisation; and occult landscapes or landscapification. These dimensions of the spectre-image function to uphold white supremacy and its reinforcing apparatuses, such as compulsory heterosexuality. I hold, in short, that Skoonheid is more productive than Kanarie in terms of its fabulation in that it raises issues related to the apartheid landscape in terms of geography, race and gender, and in so doing destabilises the echo chambers of Afrikaner assemblages to a large degree.

\section{Acknowledgements}

This work is based on the research supported wholly/in part by the National Research Foundation of South Africa (Unique Grant Number:117830).

\section{Notes}

1. See Shelley Stamp Lindsey (1991).

2. For an important exposition on queer South African film, see Marginal Lives and Painful Pasts: South African Cinema after apartheid by Martin Botha (2007).

3. See Chapter 3 in Difference and Repetition (Deleuze 1994:129-167).

4. White supremacy here does not refer to far-right or alt-right movements, or any other overt racialised political ideology. Rather, I use it here to denote structural racism. 
5. There has been some critique of Kanarie in terms of race; see for example Theolin Tembo's (2019) article.

6. I am not proposing that the spectre-image is another primary image as the movement-image and time-image are. What I am arguing is that the spectre-image is a pertinent image for our times and that it can be located in the nonlocalisable spaces in and between movement-images and time-images.

7. Deleuze and Guattari's ontology, or diagram of reality, is always in flux between the virtual, the intensive and the actual or extensive. However, it is important from the outset to recognise that there is no hierarchy between these states and that none of them exists prior to the others. The virtual or immaterial can be regarded broadly as the Ideal while the actual refers to material extensity.

8. See Derrida (1992:10), "tt]his logic of haunting would not be merely larger and more powerful than an ontology or a thinking of Being (of the "to be," assuming that it is a matter of Being in the "to be or not to be," but nothing is less certain). It would harbor within itself, but like circumscribed places or particular effects, eschatology and teleology themselves.'

9. See Chapter 7 in A thousand plateaus (Deleuze and Guattari 1987:167-191).

10. At least the South African viewer of a certain age (pre-millennial).

\section{REFERENCES}

Andrews, G. 2018. Oliver Hermanus's Skoonheid. Image \& Text 31:30-47.

Botha, M. 2007. Marginal lives and painful pasts. South African cinema after apartheid. Cape Town: Genugtig! Publishers.

Clover, C. 2014. Her body, himself: Gender in the slasher film, in Film and gender. Critical concepts in Media and Cultural Studies, edited by S Thornham and N Richardson. London and New York: Routledge:143-182.

Chen, MY. 2012. Animacies: Biopolitics, racial mattering, and queer affect. Durham, NC: Duke University Press.

Chow, R. 2002. The protestant ethnic and the spirit of capitalism. New York: Columbia University Press.

Coetzee, JM. 1997. Boyhood: Scenes from provincial life. New York: Viking.

Deleuze, G. 1986. Cinema 1. The movement-image, translated by H Tomlinson and B Hammerjam. Minneapolis: University of Minnesota Press.

Deleuze, G. 1989, Cinema 2. The time-image, translated by H Tomlinson and R Galeta. London and Minneapolis: University of Minnesota Press.

Deleuze, G. 1994. Difference and repetition, translated by P Patton. London: Athlone Press. 
Deleuze, G \& Guattari, F. 1987. A thousand plateaus. Capitalism and schizophrenia vol. 2, translated by B Massumi. London and Minneapolis: University of Minnesota Press.

Derrida, J. 1992. Given time: I. Counterfeit money, translated by P Kamuf. Chicago and London: Chicago University Press.

Derrida, J. 1994. Spectres of Marx. The state of the debt, the work of mourning and the New International, translated by P Kamuf. London and New York: Routledge.

DiAngelo, R. 2018. White fragility: Why it's so hard for white people to talk about racism. Boston: Beacon Press.

Eloff, H. 2018. Canary - A brilliant gay Afrikaans film that sings its little heart out . [O]. Available: https://www.channel24.co.za/Movies/News/canary-a-brilliant-gay-afrikaansfilm-that-sings-its-little-heart-out-20181018-2. Accessed 18 January 2019.

Falkof, N. 2016. ENG/AFR: White masculinity in two contemporary South African films. Critical Arts 30(1):15-30.

Fisher, M. 2012. What is hauntology? Film Quarterly (Fall):16-24.

Fisher, M. 2013. The metaphysics of crackle: Afrofuturism and hauntology. Dancecult: Journal of Electronic Dance Music Culture (5)2:42-55.

Freccero, C. 2013. Queer spectrality: Haunting the past, in The spectralities reader: Ghosts and haunting in contemporary Cultural Theory, edited by M del Pilar Blanco and E Peeren. London and New York: Bloomsbury Press:335-360.

Green-Simms, L. 2012. Occult melodrama: Spectral affect and West African video-film. Camera Obscura 27(2):25-59.

Guattari, F. 2016. Lines of flight, translated by A Goffey. London and New York: Bloomsbury.

Hagglund, M. 2008. Radical atheism: Derrida and the time of life. Stanford: Stanford University Press.

Hermanus, O (dir). 2011. Skoonheid. [Film]. Moonlighting Films.

Hoad, N. 2016. Queer customs against the law. Research in African Literatures 47(2):1-19.

Hochhar-Lindgren, G. 2011. Philosophy, art, and the spectres of Jacques Derrida. Amherst and New York: Cambria Press. 
Keating, A. 1995. Interrogating 'whiteness', (de)constructing 'race'. College English 57(8):901-918.

Kobayashi, A \& Peake, L. 2000. Racism out of place: Thoughts on whiteness and an antiracist geography in the new millennium. Annals of the Association of American Geographers 90(2):392-403.

Lindsey, S. S. 1991. Horror, femininity, and Carrie's monstrous puberty, in Film and gender. Critical concepts in Media and Cultural Studies. Journal of Film \& Video 43(4): 33-44.

Mahtani, M. 2014. Toxic geographies: Absences in critical race thought and practice in social and cultural geography. Social \& Cultural Geography 15(4):359-367.

Maty Bâ, S \& Higbee, W. 2012. Introduction: De-Westernizing film studies', in DeWesternizing Film Studies. London and New York: Routledge:1-15.

McKittrick, K. 2006. Demonic grounds. Black women and the cartographies of struggle. London and Minneapolis: University of Minnesota Press.

McKittrick, K \& Woods, C. 2007. Black geographies and the politics of place. Toronto: Between the Lines.

McLaren, P. 1991. Decentering culture: Postmodernism, resistance and critical pedagogy, in Current perspectives on the culture of schools, edited by NB Wyner. Boston: Brookline:232-257.

Minh-ha, T. 1989. Outside in, inside out, in Questions of Third Cinema, edited by J Pines and P Willemen. London: BFI Publishing:133-149.

Mulvey, L. 1975. Visual pleasure and narrative cinema. Screen 16(3):6-18.

Neale, S. 2014. Questions of genre, in Film and gender. Critical concepts in Media and Cultural Studies, edited by S Thornham and N Richardson. London and New York: Routledge:7-12.

Olwagen, C (dir). 2018. Kanarie. [Film]. Marche Media.

Osinubi, TA. 2016. Queer prolepsis and the sexual commons: An introduction. Research in African Literatures 47(2):vii-xxiii.

Pilar Blanco, M (del) \& Peeren, E. 2013a. Spectral subjectivities: Gender, sexuality, race/ Introduction, in The spectralities reader: Ghosts and haunting in contemporary Cultural Theory. London and New York: Bloomsbury Press:309-316, 
Pilar Blanco, M (del) \& Peeren, E. 2013b. Haunted historiographies/Introduction, in The spectralities reader: Ghosts and haunting in contemporary Cultural Theory. London and New York: Bloomsbury Press:481-488.

Price, PL. 2010. At the crossroads: Critical race theory and critical geographies of race. Progress in Human Geography 34(2):147-174.

Rogerson, CM. 1990. Defending apartheid: Armscor and the geography of military production in South Africa. GeoJournal 22(3):241-250.

Schoonover, K \& Galt, R. 2016. Queer cinema in the world. Durham and London: Duke University Press.

Sonnekus, T. 2013. "We're not faggots!": Masculinity, homosexuality and the representation of Afrikaner men who have sex with men in the film Skoonheid and online. South African Review of Sociology 44(1):22-39.

Stobie, C. 2016. "She who creates havoc here": A queer bisexual reading of sexuality, dance, and social critique in Karmen Geï. Research in African Literatures 47(2):84-103.

Taylor, C. 2000. Searching for the postmodern in African cinema, in Symbolic narratives/ African cinema. Audiences, theory and the moving image, edited by J Givanni. London: BFI Publishing:136-144.

Taylor, Y. 2016. Fitting into place? Class and gender geographies and temporalities. London and New York: Routledge.

Tembo, T. 2018. Kanarie - review. [O]. Available: https://www.iol.co.za/capeargus/life/kanarie-review-17523145. Accessed 24 January 2019.

Tomaselli, K, Shepperson, A \& Eke, M. 1999. Towards a theory of orality in African cinema, in African cinema. Post-colonial and feminist readings, edited by KW Harrow. Asmara and Trenton: Africa World Press, Inc.:45-71.

Tuck, E \& Ree, C. 2013. A glossary of haunting, in Handbook of autoethnography, edited by JS Holman, TE Adams and C Ellis. Walnut Creek, CA: Left Coast Press, Inc.:639-658.

Verwey, C \& Quayle, M. 2012. Whiteness, racism, and Afrikaner identity in post-apartheid South Africa. African Affairs 111(445):551-575.

Wenzel, J. 2000. The pastoral promise and the political imperative: The plaasroman tradition in an era of land reform. Modern Fiction Studies 46(1):90-113. 
Williams, L. 2014. Film bodies: Gender, genre, and excess, in Film and gender. Critical concepts in Media and Cultural Studies, edited by S Thornham and $\mathrm{N}$ Richardson. London and New York: Routledge:39-53.

Willoughby-Herard, T. 2014. "The only one who was thought to know the pulse of the people": Black women's politics in the era of post-racial discourse. Cultural Dynamics 26(1):73-90. 